\title{
PEMANFAATAN QUIZ BOT TELEGRAM DALAM PEMBELAJARAN MENYIMAK BAHASA INGGRIS
}

\author{
Rahmad Hidayat ${ }^{1}$, Fajar Susanto ${ }^{2}$, Endang M. Rahayu ${ }^{3}$, \\ Hertiki ${ }^{4}$, Armelia N. Arbani ${ }^{5}$, Joesasono O. Soelistijowati ${ }^{6}$ \\ Fakultas Ilmu Sosial dan Humaniora, Universitas PGRI Adi Buana Surabaya \\ email : rahmadhidayat@unipasby.ac.id, fajarsusanto@unipasby.ac.id
}

\begin{abstract}
Abstrak
Peguasaan dan pemanfaatan teknologi untuk menunjang keberhasilan pembelajaran sudah menjadi keharusan dan tuntutan di era Revolusi Industri 4.0, terlebih di masa pandemi COVID-19. Guru sebagai garda terdepan untuk kemajuan pendidikan dengan demikian harus membekali diri dengan teknologi pembelajaran berupa Sistem Manajemen Pembelajaran atau Learning Management System (LMS) seperti Google Classroom, Edmodo, Canvas, Telegram dan lain sebagainya. Oleh karena itu, artikel ini bertujuan untuk menjelaskan tentang pembekalan penggunaan Telegram Quiz Bot sebagai sarana pembelaran materi Bahasa Inggris, khususnya materi menyimak. Pembekalan diberikan kepada para guru tingkat SMA baik Negeri maupun Swasta yang tergabung dalam Musyawarah Guru Mata Pelajaran (MGMP) Bahasa Inggris di wilayah Surabaya. Quiz bot menjadi salah satu pilihan menarik bagi guru untuk mempermudah KBM secara daring serta meningkatkan kualitas pembelajaran di masa pandemi. Hal itu karena Quiz bot memiliki beberapa manfaat lebih sebagai media pembelajaran materi menyimak yakni menyediakan sarana pembuatan soal pilihan ganda, fitur poling, deskripsi kuis, teks dan gambar, serta yang paling penting adalah audio. Selain itu, quiz bot mudah digunakan dan tersedia failitas audit di dalamnya.
\end{abstract}

Kata kunci: Quiz bot, Learning Management System (LMS), menyimak.

\begin{abstract}
The use of technology to support the successful of learning process is an obligation in the era of Revolution of Industry 4.0 especially at the time of covid-19 pandemic. As the front liner in the education system, teacher should improve their teaching quality by having good knowledge on Learning Management System (LMS) as a means to teach. There are lot of LMS as the supporting system in teaching process such as Google Classroom, Edmodo, Canvas, Telegram, etc. For the reason, this article aims to explain the provision of using of the Telegram Quiz Bot as a means of teaching English language, especially listening skills. The provision was given to the teachers who teach in both public and private high school. The teachers are members of the English Subject Teacher Conference (MGMP) in the Surabaya area. Quiz bots can be a fascinating option for teachers to facilitate online teaching and learning and improve the quality of learning during the pandemic. This is because the Quiz bot has several more benefits as a learning media for listening skills, namely providing a means of making multiple choice questions, polling features, quiz descriptions, text and images, and most importantly audio. In addition, the quiz bot is easy to use and provide auditing facility.
\end{abstract}

Keywrods: quiz bot, Learning Management System (LMS), listening. 


\section{PENDAHULUAN}

Penggunaan sistem manejemen pembelajaran atau learning management system (LMS) dalam kegiatan pembelajaran di sekolah bukanlah sebuah hal yang baru. Aplikasi atau LMS menjadi sebuah keniscayaan yang tak terelakkan lagi yang harus dikuasai oleh semua pemangku kepentingan dalam dunia pendidikan, utamanya oleh guru sebagai pendidik yang berada di garis terdepan bagi kemajuan bangsa. Oleh karenanya, pemanfaatan LMS di masa sekarang dan tentunya masa depan sangat berkontribusi besar bagi pengembangan dan kemajuan proses belajar serta pendidikan secara keseluruhan.

Merebaknya Covid-19 sebagai pandemi yang melanda Indonesia bahkan hampir seluruh negara di dunia makin menegaskan pentingnya penguasaan LMS sebagai sarana penunjang pembelajaran. Dampak langsung bagi dunia pendidikan adalah aktivitas belajar dari rumah untuk menghidari merebaknya virus yang sangat cepat. Menteri Pendidikan dan Kebudayaan (Mendikbud) Republik Indonesia bahkan mengeluarkan Surat Edaran No 4 Tahun 2020 tentang Pelakasanaan Kebijakan Pendidikan dalam Masa Darurat Penyebaran Covid19. Nomor dua poin a dalam Surat Edaran Mendikbud tersebut menjelaskan bahwa belajar dari rumah melalui pembelajaran daring/jarak jauh dilaksanakan untuk memberikan pengalaman belajar yang bermakna bagi siswa

(http://pgdikmen.kemdikbud.go.id/readnews/surat-edaran-mendikbud-nomor4-tahun-2020).

Sejak pemberlakukan belajar dari rumah sebagai dampak virus corona, aktitias pembelajaran daring pun menjadi sebuah pilihan yang tidak bisa dihindari karena semua sekolah tutup demi menghindari terpaparnya virus. Semua guru dan murid harus membiasakan diri untuk menggunakan LMS sebagai sarana pembelajaran pengganti tatap muka yang tidak bisa dilakukan sebagaimana saat kondisi normal. Hal ini sejalan dengan tuntutan bahwa guru harus professional dengan mengikuti setiap perkembangan di dunia pendidikan yang selalu bergerak dinamis. (Etistika Yuni W dkk, 2016; Muhammad Hanafi, 2017).

Guru yang profesional harus memiliki kompetensi yang dipersyaratkan dalam profesi guru. Menurut Surya dkk (2004:4.24) kompetensi guru adalah seperangkat penguasaan kemampuan yang harus ada dalam diri guru agar dapat mewujudkan penampilan unjuk kerja sebagai guru secara tepat. Dalam Undang Undang Nomor 14 tahun 2005 pasal 10 ayat 1 kompetensi guru dikelompokkan menjadi 4 kelompok, yaitu (1) kompetensi pedagogik, (2) kompetensi kepribadian, (3) kompetensi sosial, dan (4) kompetensi profesional. Kompetensi pedagogik adalah kemampuan mengelola pembelajaran peserta didik antara lain: (1) terampil melakukan kegiatan pengembangan yang mendidik, serta (2) terampil melakukan penelitian, penilaian dan evaluasi proses dan hasil belajar, (3) memanfaatkan hasil penelitian, penilaian dan evaluasi untuk kepentingan pembelajaran.

Kompetensi profesional merupakan kemampuan penguasaan materi pelajaran secara luas dan mendalam. Salah satu upaya yang dapat dilakukan guru profesional untuk meningkatkan kualitas pembelajaran adalah melalui pemanfaatan media online sebagai sarana dalam pembelajaran Bahasa Inggris di masa 
Pandemi saat ini. Paul Gruba (2018) dalam artikelnya bertajuk Technology for Teaching Listening mengatakan bahwa siswa di abad 21 sebagai generasi digital membutuhkan penggunaan teknologi sebagai penunjang pembelajaran bahasa Inggris khususnya keahlian menyimak.

Konsep yang digunakan dalam pengabdian masayarakat ini adalah Technoolgy Acceptance Model (TAM) atau model penerimaan teknologi. Konsep TAM ini menurut Munir (2010) adalah sebuah perangkat tentang penerimaan penggunaan teknologi sebagai sarana untuk menunjang pembelajaran. Salah satu unsur penting dari konsep TAM tersebut adalah teknologi yang digunakan dalam pembejalaran memberikan kemudahan bagi peserta didik serta dapat diterima untuk proses kegiatan belajar.

Selanjutnya Munir juga menjelaskan bahwa pengembangan konsep TAM dimulai pada tahun 1989 yang dilakukan oleh Davis dan kemudian dipertegas dengan beberapa peneliti lainnya yang membuktikan bahwa konsep TAM memiliki beberapa kelebihan yakni model ini selain sederhana juga mudah untuk diterapkan dalam pembelajaran.

Selanjutnya

Munir mengguraikan lebih lanjut bahwa konsep TAM dalam pembelajaran sebagaimana dikembangkan oleh Davis, bahwa harus mempunyai empat kriteria. Diantaranya adalah bahwa LMS yang digunakan dalam pembelajaran haruslah mudah dipejalari, mudah mengerjakan aktivitas yang diinginkan dan dibutuhkan oleh pengguna, bisa digunakan sebagai penigkatan ketrampilan oleh pengguna dan mudah dioperasikan.
Salah satu aplikasi yang dapat digunakan bagi para guru adalah Quiz Bot yang difasilitasi oleh Telegram. Telegram saat ini sangat digemari oleh khalayak ramai mengingat fitur yang ditawarkan lebih mudah untuk digunakan terutama dalam pembelajaran daring. Dengan bantuan Quiz Bot, para guru dapat membuat kuis multi-pertanyaan dan membagikannya dengan siswa. Quiz Bot juga untuk menambahkan teks atau media sebelum pertanyaan dibagikan ke siswa. Adapun jenis tes yang ditawarkan oleh Quiz Bot dapat berupa grafik dan tabel - atau tes Know Your Meme (Oris Krianto Sulaiman, 2020).

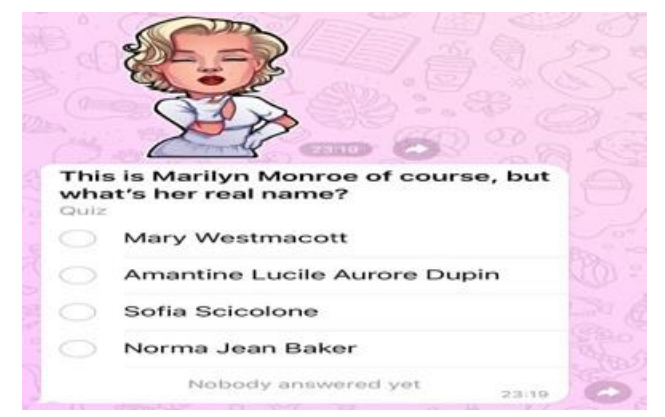

Berdasarkan uraian di atas, perlu dipertimbangkan untuk diadakan kegiatan pelatihan cara membuat soal melalui Quiz Bot dalam pembelajaran bahasa Inggris bagi para guru SMA. Kegiatan pelatihan dibatasi bagi guruguru SMA mata pelajaran Bahasa Inggris se-Kotamadya Surabaya dan hanya difokuskan pada peningkatan kemampuan guru-guru dalam memanfaatkan Quiz Bot Telegram terutama dalam keterampilan menyimak. Harapannya, setelah pelatihan, guru-guru menjadi lebih aktif dan produktif dalam menghasilkan kuis yang menarik melalui Quiz Bot Telegram . 


\section{METODE PELAKSANAAN}

Metode yang digunakan dalam program pengabdian kepada masyarakat ini adalah metode workshop atau loka karya dalam bentuk bimbingan teknis. Melalui loka karya tersebut pelaksanaan kegiatan benar-benar memperhatikan proses dari penjelasan materi hingga pembuatan LMS yang dilakukan oleh para guru sebagai peserta kegiatan pengabdian pada masyarakat ini. Sehingga pada akhir kegiatan, para peserta tidak hanya bisa membuat quiz bot akan tetapi juga menggunakannya secara langsung sebagai sarana pembelajaran Bahasa Inggris khususnya materi keahlian menyimak.

Selanjutnya, eksplanatori atau penjelasan dan pemaparan yang dilakukan secara daring dan metode pendampingan untuk pembuatan aplikasi quiz bot sebagai sarana pembelajaran keahlian menyimak. Metode ekspalanatori dilakukan dengan pemberian pelatihan dalam bentuk ceramah kepada guru-guru pengajar Bahasa Inggris tingkat SMA Surabaya baik negeri maupun swasta. Adapun metode pendampingan dilakukan sebagai tindak lanjut pelatihan dengan memberikan arahan secara terperinci tentang pembuatan hingga operasional quiz bot sebagai sarana pembelajarn untuk siswa-siswa tingkat SMA.

Pelaksanaan loka karya dan bimbingan teknis dilakukan selama 32 jam yang terbagi dalam beberapa pertemuan selama bulan September dan Oktober tahun 2020. Adapun kegiatan worksop untuk penjelasan materi dilakukan secara daring menyesuaikan dengan kondisi yang masih dalam situasi pandemi dengan menggunakan platform zoom. Sementara untuk kegiatan bimbingan teknis dilakukan dengan pertemuan dari serta pembuatan grup melalui Telegram sebagai sarana informasi dan tanya jawab.

$$
\text { Kegiatan pertama adalah }
$$
penyampaian materi pelatihan dalam membuat quiz bot telegram. Kegiatan kedua merupakan pendampingan pembuatan Telegram Quiz Bot dimana para peserta telah mempersiapkan jenis soal pilihan ganda dan simakan yang akan digunakan dalam membuat Quiz Bot. Tahap selanjutnya adalah kegiatan ketiga yang merupakan tahap pendampingan tindak lanjut. Dalam kegiatan bimtek ini, para guru membuat lengkap contoh soal kuis yang sedianya akan digunakan untuk siswa di sekolah dengan menyesuaikan waktu pembelajaran. Peserta juga diharapkan untuk bertanya dan meminta masukan jika mengalami kendala.

Sebagaimana tujuan awal bahwa pelatihan ini sebagai sebuah alternative pembelajaran secara daring, maka pelatihan dari awal hingga akhir benarbenar memanfaatkan semaksimal mungking platform aplikasi sehingga para guru nantinya bisa secara langsung menerapkannnya di pelajaran Bahasa Inggris yang selama ini mereka ajarkan di sekolah. Adapun target pelatihan adalah guru SMA baik negeri maupun swasta se Surabaya yang tergabung dalam Musyawarah Guru Mata Pelajaran (MGMP) Bahasa Inggris sebanyak 40 peserta.

\section{HASIL DAN PEMBAHASAN}

A. Pentingnya Keahlian Menyimak

Keahlian menyimak merupakan salah satu kemampuan yang sangat penting untuk menguasai bahasa, utamanya Bahasa Inggris. Bahkan penggunaannya lebih sering digunakan dibandingkan dengan keahlian lain seperti membaca, berbicara dan menulis. Mengutip Gilbert, Abbas Pourhossen $G$ dan Mohammad Reza 
Ahmadi (2011) mengatakan bahwa kegiatan menyimak secara persentasi lebih banyak dilakukan daripada keahlian lainnya dan menampati 60 sampai 80 persen dibandingkan dengan penggunaan membaca, berbicara dan menulis.

Ranukadevi (2014) juga
mengungkapkan pentingnya
pengembangan pengajaran menyimak
dalam Bahasa Inggris. Menurutnya,
kontribusi kemampuan menyimak
dalam penguasaan Bahasa jauh lebih
besar dibandingkan dengan empat
keahlian lain seperti membaca, menulis
dan berbicara. Hal ini karena menyimak
merupakan keahlian pertama yang
diterima oleh manusia. Selain itu suara,
ritme, intonasi dan tekanan yang
merupakan kemampuan mendasar
dalam mempelajari bahasa juga hanya
dapat diterima secara sempurna melalui
keahlian menyimak dengan baik.

Selanjutnya Andi Tenri Tampa (2015) dalam penelitiannya tentang pengajaran materi keahlian menyimak dalam Bahasa Inggris mengungkapkan bahwa pembelajaran menyimak haruslah disampaikan dengan menarik. Materi menyimak harus memperhatikan pengadaan sarana penunjang tidak hanya audio sebagai materi utama melainkan didukung dengan pemberian teks, gambar visual, serta animasi atau tampilan menarik lainnya.

Dengan pertimbangan di atas, penggunaan LMS yang tepat menjadi hal penting dalam pengajaran keahlian menyimak. Hal ini tentu sesuai dengan quiz bot yang memenuhi kriteria tersebut. Telegram quiz bot adalah sebuah bot (aplikasi/platform) yang dibuat oleh Aplikasi Telegram untuk membuat kuis dengan pertanyaan pilihan atau dengan melampirkan teks atau media sebelum pertanyaan. Dengan kata lain, kita juga bisa membuat gambar, teks, dan pertanyaan dengan pilihan ganda.

Quiz bot menjadi salah pilihan menarik karena penyedia LMS ini adalah Telegram yang penggunanya menunjukkan peningkatan berarti terutama pada saat pandemic covid-19 yang telah terjadi selama lebih dari tujuh bulan. Sutrisno Zulkifli (https://teknologi.id/aplikasi/6-bulanterakhir-pengguna-aktif-telegram-naik100-juta) mengatakan bahwa terjadi kenaikan drastic pemakai Telegram saat pandemic covid-19 yakni sekitar 1,5 juta pengguna per hari dalam enam bulan belakangan. Catatan ini memberikan gambaran bahwa masyarakat makin akrab dengan aplikasi Telegram.

\section{B. Quiz Bot sebagai Media Pembelajaran Menyimak}

Sebagaimana pembahasan di atas, penggunaan LMS sebagai media pembelajaran sudah menjadi kenormalan baru dalam dunia pendidikan. Jika sebelumnya penggunaan LMS lebih banyak hanya sebagai pendukung pengajaran, maka merebaknya Covid-19 sebagai pandemi membuat LMS menjadi pilihan utama dalam pengajaran. Banyak para ahli pendidikan juga mengatakan bahwa penggunaan LMS pasca pandemi akan makin meningkat dibandingkan sebelumnya seiring dengan makin akrabnya baik guru maupun siswa terhadap penggunaan LMS.

Perkembangan pembelajaran secara daring pun berbanding lurus dengan makin bervariasinya platform atau LMS. Hal ini memberikan kontribusi besar bagi dunia pendidikan karena menciptakan berbagai peluang dan pilihan dalam mengembangkan 
proses pembelajaran melalui LMS sebagai sarana pendukung. Pada titik tersebut, pemilihan quiz bot bagi guru SMA baik negeri maupun swasta di Surabaya bisa menjadi pilihan yang menarik. Oleh karenanya, pelatihan yang dilakukan diharapkan memberikan kontribusi bagi para guru untuk menggunakan quiz bot.

Beberapa hal penting yang diberikan kepada guru-guru SMA se Surabaya meliputi keunggulan dan kelebihan dalam menggunakan quiz bot telegram serta bagaimana membuatnya sehingga bisa diaplikasikan secara baik. Persoalan mendasar pertama yang harus dipahami oleh peserta pelatihan adalah mengenali fitur yang terdapat dalam quiz bot. Fitur tersebut memiliki kegunaan yakni kuis dengan pilihan ganda, mengunggah media maupun teks sebelum pertanyaan, menentukan judul dan deskripsi kuis, mengedit kuis, dan membagikan kuis.

Pemaparan selanjutnya adalah penjelasan mengenai kelebihan fitur quiz bot Telegram. Diantaranya adalah menyediakan sarana untuk membuat soal pilihan ganda, menyediakan fitur poling, menyediakan fasilitas untuk membuat judul dan deskripsi dari kuis, pengguna Quiz Bot dapat menambah media dalam bentuk teks, gambar dan audio (simakan), Quiz Bot telegram juga mudah digunakan terutama dalam fitur berbagi dalam chanel, grup dan kontak, kemudian mudah untuk di edit kembali jika dirasa ada yang perlu diperbaiki.

\section{Pembuatan Quiz Bot}

Adapun langkah-langkah pembuatan quiz bot dijelaskan secara terperinci sebagai berikut:

1) Membuka aplikasi telegram lalu cari Quiz Bot

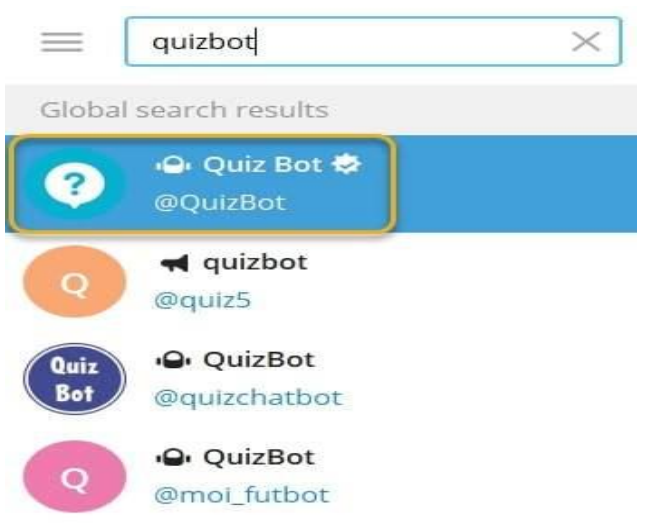

Gambar 2.

2) Memilih kuis baru atau new quiz

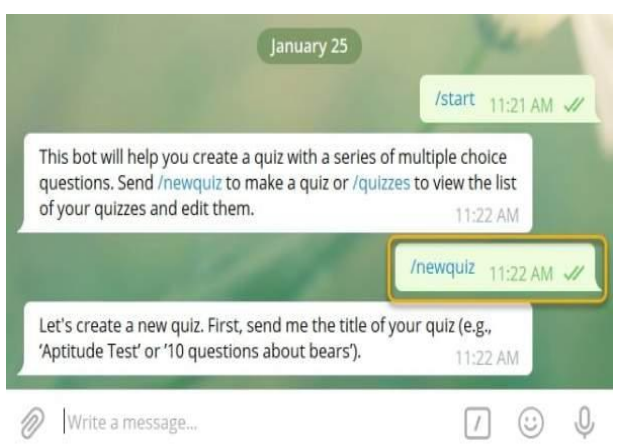

Gambar 3.

3) Menambahkan judul untuk kuis, misalnya: Telegram Quiz Bot Guide. Selain itu bisa juga diganti dengan Post-Intermediate Listening Quiz

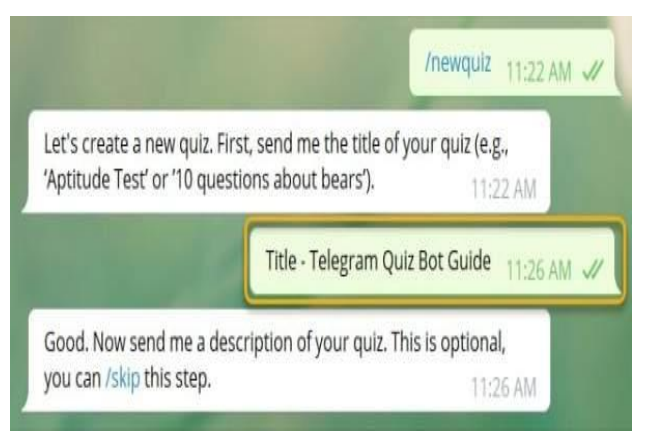

Gambar 4. 
4) Menentukan deskripsi dari kuis yang dibuat.

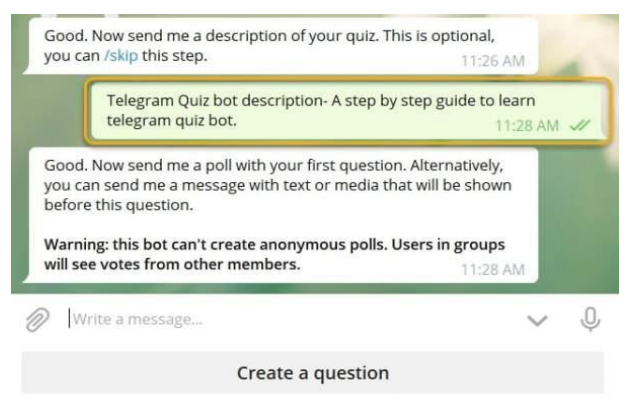

\section{Gambar 5.}

Jika tidak ingin menambahkan deskripsi kuis maka bisa langsung melewatinya dengan mengetik perintah /skip.

5) Fitur untuk menambah teks sebelum pertanyaan

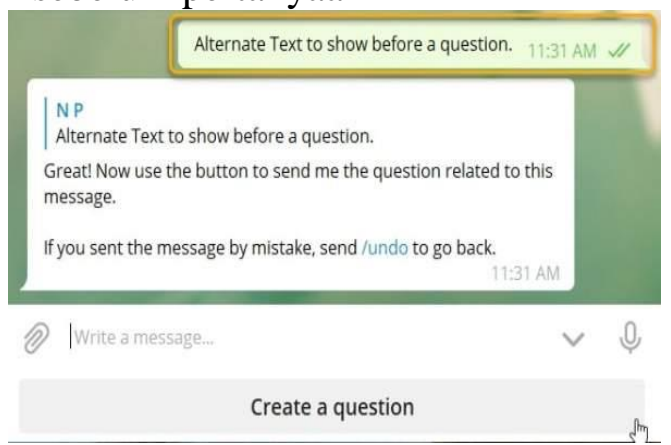

\section{Gambar 6}

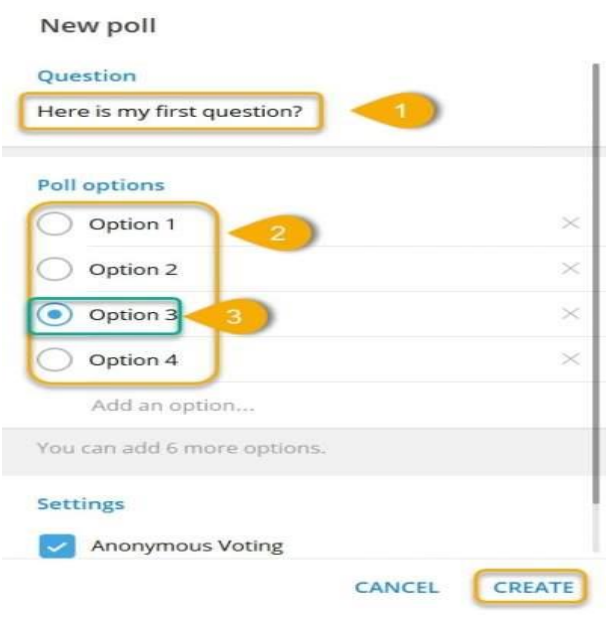

Gambar 7.
Tahap ini pilihan atau optional, jadi bisa dilakukan maupun tidak. Jika dirasa perlu untuk menambahkan teks sebelum bacaan, maka hal ini bisa juga dilakukan. Selain itu tidak hanya teks bacaan tetapi juga audio dengaran. Sama halnya juga dengan fitur polling.

6) Membuat Pertanyaan

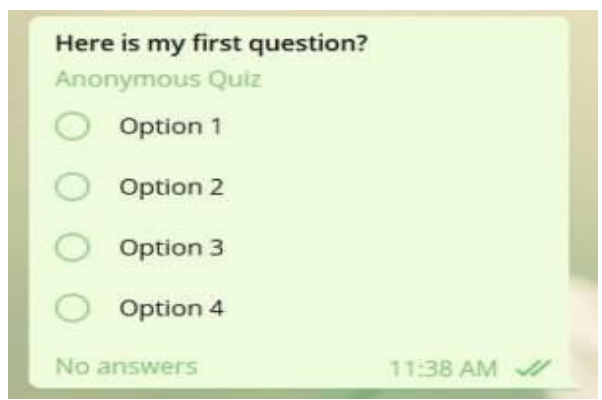

Gambar 8.

Step berikutnya ini yang perlu diperhatikan terutama dalam membuat pertanyaan untuk kuis. Ada tiga hal yang perlu diperhatikan yakni menentukan pertanyaan-pertanyaan yang akan digunakan dalam Quiz Bot, menambahkan pilihan jawaban dan menandai jawaban yang paling benar.

Setelah selesai dengan tahapan di atas, berikutnya klik tombol create. Lalu akan muncul, tanda polling Anonymous dan abaikan saja. Berikut ini merupakan contoh kuis saat Anda selesai membuat pertanyaan. "Good, Your Quiz Title -Telegram Quiz Bot Guide now has 1 question". Seandainya Anda melakukan kesalahan dan ingin menggantinya, tinggal klik sending/undo. Sekarang, kirim poin berikutnya yang berupa teks maupun media seperti yang sebelumnya. Ketika Anda sudah yakin dengan apa yang Anda kerjakan tinggal klik/done untuk menyelesaikan kuisnya.

7) Tentukan waktu dan ubah susunan 
pertanyaan.

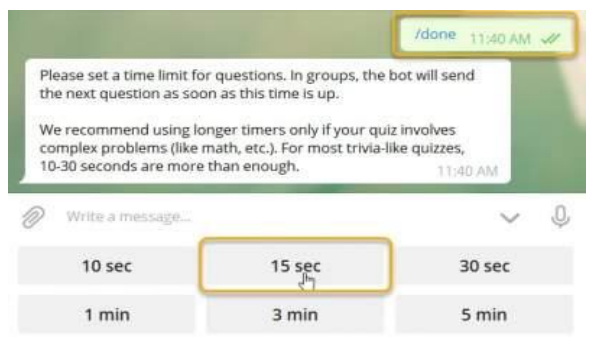

Gambar. 9.

Setelah Anda mengetik /done, silakan memilih batasan waktu untuk mengerjakan setiap pertanyaan. Pengguna dapat menjawab pertanyaan begitu waktu dimulai. Pilihan waktu yang tersedia adalah 10 detik, 15 detik, 30 detik, 1 menit, 3 menit, dan 5 menit. Pengguna dapat memilih waktu sendiri waktu yang tersedia. Quiz Bot Telegram juga menyediakan pilihan acak pertanyaan dan jawaban. Jadi tinggal menjawab Ya atau Tidak.

8) Kuis siap digunakan

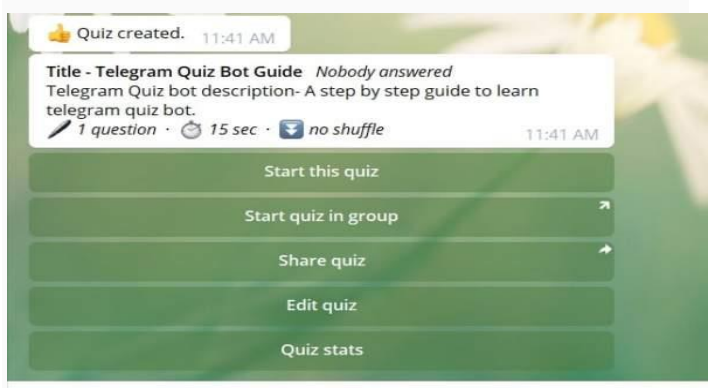

\section{Gambar 10.}

Kuis telah siap digunakan hanya dengan tujuh cara. Dari gambar di atas, Anda dapat melihat contoh kuis yang telah dibuat. Judul kuis "Title - Telegram Quiz Bot Guide", deskripsi kuis dan waktu yang tersedia.

\section{Cara Mengubah Quiz Bot}

Apakah kuis yang telah kita buat dapat diubah? Jawabannya adalah tentu saja iya. Berikut ini adalah tahapan cara memperbaiki pertanyaan-pertanyaan kuis:

1) Klik edit image. Dengan menekan tombol edit image, maka secara otomatis Anda dapat mengubah tombol kuis. Tombol ini akan keluar saat Anda membuat kuis atau memilih kuis. Tidak hanya itu saja, Anda juga dapat memilih kuis dengan mengetik /quizzes

2) Pilih bagian yang ingin Anda edit. Setelah tahap pertama, Anda akan mendapat kesempatan untuk bagian mana yang ingin Anda edit. Seperti mengedit pertanyaan, judul, deskripsi, waktu, serta mengedit setingan shuffle.

\section{Cara Membagikan Quiz Bot}

Sekarang kita tahu bagaimana cara membuat dan mengedit kuis. Berikut ini merupakan cara untuk membagikan kuis yang telah kita buat di kelompok, channel dan kontak yang tersedia.

1) Membagikan materi di kelompok telegram.

a. Pilih bagikan kuis di pilihan grup. Saat kita memilih kuis yang telah diubah, pilihan ini juga tersedia disana.

b. Pilih kelompok yang Anda ingin bagikan.

2) Membagikan materi di channel and kontak.

Klik Share Quiz. Pilihan ini tersedia di bagian bawah share quiz in-group button. Kemudian Pilih percakapan yang diinginkan, bisa melalui kontak per individu maupun channel.

\section{Pendampingan dalam Pembuatan}




\section{dan Penggunaan Quiz Bot}

Tahap ini merupakan tahap yang sangat penting dan menentukan dalam keberhasilan penggunaan quiz bot Telegram. Sebagaimana konsep awal bahwa kegiatan ini bersifat pendampingan kepada guru-guru bahasa Inggris SMA negeri dan swasta se surabaya, maka melalui pendampingan tersebut para guru bisa membuat quiz bot sehingga memberikan pilihan yang beragam dalam penggunaan LMS sebagai media pembelajaran. Oleh karena itu beberapa aspek pendampingan yang dilakukan meliputi (1) pembuatan media sosial telegram sebagai wadah komunikasi dengan para guru pasca pelatihan secara daring; (2) pemberian konsultasi kepada guru yang membuat quiz bot; serta (3) pendampingan konsultasi kepada guru saat mereka menghadapi kendala baik pada saat pembuatan quiz bot maupun operasional LMS tersebut dalam kegiatan pembelajaran.

Pendampingan kepada guru dimulai pasca pelatihan secara daring dengan membuat forum diskusi melalui media sosial telegram. Dengan pembuatan grup yang diberi nama PPM BING 1-20, grup telegram berisikan 61 anggota meliputi para guru dan pendamping Pengabdian Masyarakat dari pihak program studi Pendidikan bahasa Inggri Universitas PGRI Adi Buana Surabaya. Salah satu hal menarik dari grup telegram ini adalah tidak hanya sebagai media pendampingan pembuatan quiz bot saja, tetapi juga menjadi sarana baru bagi para guru untuk berdiskusi khususnya tentang media quiz bot.

Seorang guru bernama Willy Sucahyo P.S. dalam grup Telegram mengatakan bahwa grup ini bisa menjadi ajang berbagi pengalaman sehingga antara satu guru dengan guru lain bisa saling memberi dan menerima pengetahuan. Sementara itu, beberapa nama yang aktif dalam grup itu diantaranya adalah Miki Hartono, Mrs Yuyun Studyawati, serta ketua MGMP Theo Gunawan Wahana. Dalam obrolan di grup, para guru saling memberikan semangat dalam bahasa Inggris sesuai dengan profesi mereka sebagai guru bahasa Inggris seperti ungkapan, "Good morning boss. Lovely morning to start the day", "Hallo good morning, we hope all of us are always in God's protection," serta balasan "Good morning bapak/ibu. I hope everyone's fine and healthy."

Hal kedua adalah pendampingan pembuatan quiz bot telegram dengan memberikan konsultasi yang dilakukan melakukan grup telegram. Salah satu pertanyaan yang muncul adalah pertanyaan yang dikemukakan oleh Miki Hartono yang menanyakan tentang bagaimana cara mengirim tautan atau link quiz bot telegram setelah selesai dibuat. Jawaban bisa dilihat dari gambar berikut.

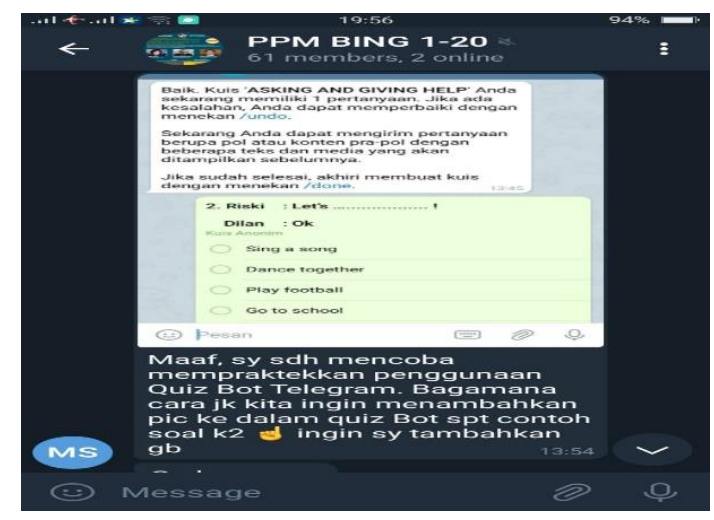

Jawaban tersebut mendapat respon cukup baik dari Mrs. Yuyun S yang menyatakan bahwa ia akan segera mencoba membuat serta mempraktikannya serta tak lupa mengucapkan terima kasih terhadap jawaban yang diberikan.

Tahap ketiga adalah pendampingan terhadap permasalahan yang dihadapi oleh guru pada saat menggunakan quiz bot. Hal ini dilakukan oleh Miki Hartono ketika ia menghadapi kendala membagikan tautan atau link kepada siswa. Sebagaimana gambar berikut: 


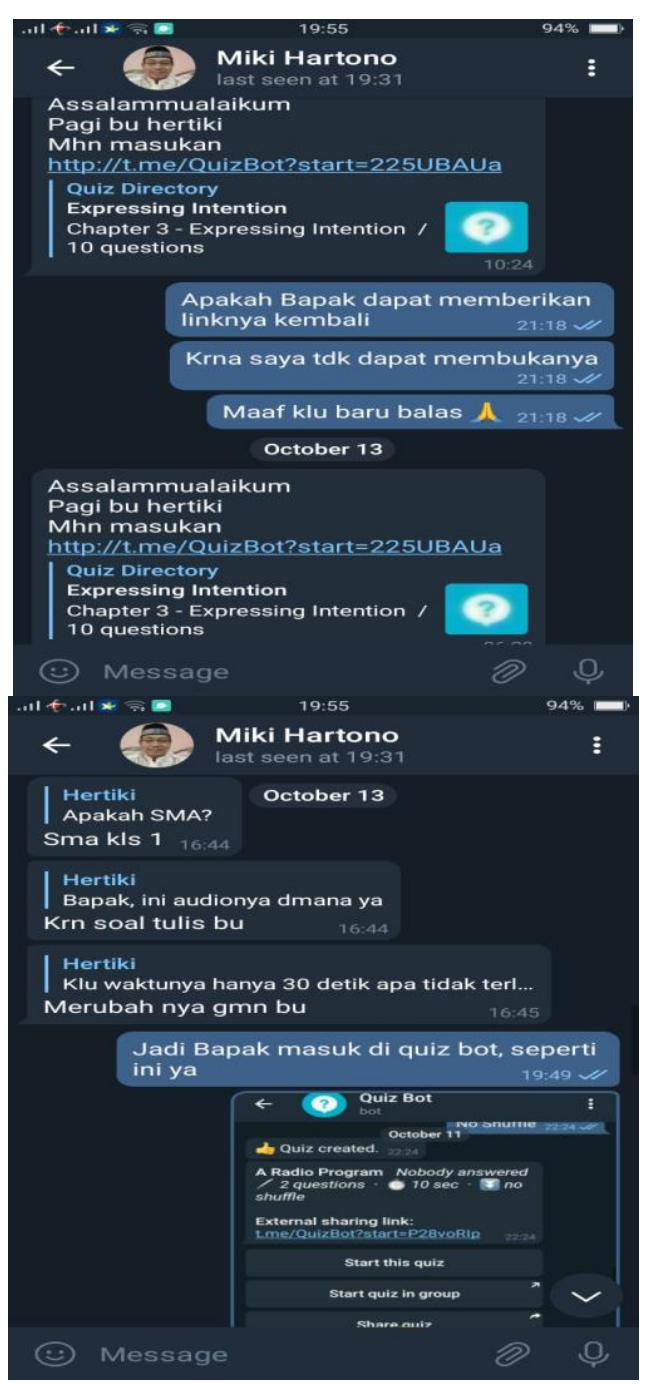

Pemberian solusi diberikan dengan membantu Miki Hartono untuk membuka link yang diberikan untuk pengecekan kendala yang dihadapi serta jalan keluarnya.

Selain itu, Miki Hartono juga melakukan konsultasi terkait dengan isi materi pembelajaran menyimak dalam bahasa Inggris. Miki membuat materi menyimak dengan topik expressing intention yang dilengkapi dengan 10 pertanyaan. Sebagaimana pembekalan yang diberikan, materi yang diberikan serta penggunaan quiz bot yang dilakukan oleh Miki Hartono cukup bagus dan memenuhi kriteria sesuai dengan materi yang diberikan yakni pemanfaatan quiz bot sebagai sarana pembelajaran bahasa Inggris khususnya materi keahlian menyimak.

\section{SIMPULAN}

Sebagai salah satu LMS, quiz bot memberikan tidak hanya kemudahan sebagai sarana pembelajaran bahasa Inggris khususnya untuk peningkatan keahlian menyimak. Quiz bot juga memberikan berbagai fitur yang sangat sesuai dengan pembelajaran kemampuan menyimak seperti yakni menyediakan sarana pembuatan soal pilihan ganda, fitur poling, deskripsi kuis, teks dan gambar, serta yang paling penting adalah audio.

\section{REFERENSI}

Ampa, Andi Tenri. (2015). The Implementation of Interactive Multimedia Learning Materials inTeaching Listening Skills. English Language Teaching; Vol. 8, No. 12; 2015 ISSN 1916-4742 EISSN 1916-4750 Published by Canadian Center of Science and Education.

Hanafi, Muhammad. (2017). Membangun Profesional Guru dalam Bingkai Pendidikan Karakter. Jurnal Ilmu Budaya. Volume 5, Nomor 1 Juni 2017. ISSN 2354-7294.

Hernawan, B. (2020). Telegram Messenger Lengkapi Fitur Pols dengan Quiz Mode. Jakarta: Kompas Gramedia.

Johnston, D. (2020). Leading with Quizbot. Chicago: Human Learning Tools. https://learningtools.donjohnston.com Lproduct/quizbot/

Kusuma, I.P.I. (2020). Mengajar Bahasa Inggris dengan Teknologi. Teori Dasar dan Pengajaran. Deep Publish. Jogjakarta.

Gruba, Paul (2018). Technology for Teaching Listening. The TESOL Encycplodia of English Language Teaching. First edition. Edited by 
John I. Liontas. John Wiley \& Son, Inc.

Munir. (2010). Penggunaan Learning Management System (LMS) di Perguruan Tinggi: Studi Kasus di Universitas Pendidikan Indonesia. Cakrawala Pendidikan Th. XXIX. No.1.

Renukadevi. D. (2014). The Role of Listening in Language Acquisition; the Challenges \& Strategies in Teaching Listening. International Journal of Education and Information Studies. ISSN 22773169 Volume 4, Number 1, pp. 59-63.

Sulaiman, Oris K. (2020). Inovasi Pembelajaran di era Covid-19. Yayasan Kita Menulis.

Surat Edaran Menteri Pendidikan dan Kebudayaan (Mendikbud) Republik Indonesia No. 4 Tahun 2020 tentang Pelakasanaan Kebijakan Pendidikan dalam Masa Darurat Penyebaran Covid-19.

http://pgdikmen.kemdikbud.go.id/read -news/surat-edaran-mendikbudnomor-4-tahun-2020

Surya, HM. (2004). Kapita Selekta Kependidikan SD, Universitas Terbuka.

https://teknologi.id/aplikasi/6-bulanterakhir-pengguna-aktif-telegramnaik-100-juta. diakses pada tanggal 20 Oktober 2020.

Wijaya, Etistika Yuni, Dwi Agus Sudjimat, Amat Nyoto. (2016). Transformasi Pendidikan Abad 21 sebagai Tuntutan Sumber Daya Manusia di Era Global. Prosiding Seminar Nasional Pendidikan Matematika. Universitas Kanjuruhan Malang. Volume 1 Tahun 2016-ISSN 2528 - 259X. 